\title{
POROZUMIENIE STRONNICTW DEMOKRATYCZNYCH 1948-1950 - PRÓBA KONSOLIDACJI POLSKIEJ EMIGRACJI POLITYCZNEJ
}

\author{
Abstract \\ AGREEMENT OF DEMOCRACTIC PARTIES IN THE YEARS 1948-1950 - \\ AN ATTEMPT TO CONSOLIDATE THE MILIEU \\ OF POLISH POLITICAL IMMIGRATION
}

After his arrival to London in 1947, Stanisław Mikołajczyk undertook endeavors to form a national committee, which would be a projection of the World War II quadruple agreement, which brought together Polish Peasant Party (Polskie Stronnictwo Ludowe), Polish Socialist Party (Polska Partia Socjalistyczna), Labor Party (Stronnictwo Pracy) and National Party (Stronnictwo Narodowe). The creation of the Agreement of Democratic Parties was to be the initial step towards the future cooperation and functioning. Yet the National Party was not interested in such cooperation and the Agreement turned out to be a weak entity, unable to conduct active policy among Polish emigration. Differences between parties proved to be too big a barrier, among others regarding the question of the legality of Polish government in exile. The final blow to Mikołajczyk's concept was the creation of Political Council by National Party, Polish Socialist Party and the Polish Liberty Movement “Independence and Democracy” (Polski Ruch Wolnościowy „Niepodległość i Demokracja”).

Keywords: emigration, Peasant Party activists, socialists, Christian Democrats, agreement Słowa kluczowe: emigracja, ludowcy, socjaliści, chadecy, porozumienie

Przybycie zagrożonego aresztowaniem w Polsce Stanisława Mikołajczyka do Wielkiej Brytanii w październiku 1947 r. wprowadziło nowy element do i tak już skomplikowanej sytuacji politycznej polskiej emigracji. Liderom ugrupowań emigracyjnych przybył poważny 
rywal polityczny. Każde z ugrupowań musiało zająć stanowisko wobec osoby Mikołajczyka i realizowanej przez niego polityki ${ }^{1}$. Większość emigracyjnej elity politycznej przyjęła go chłodno, wręcz nieprzyjaźnie. Wskazywano na klęskę jego koncepcji politycznej, „kolaborację" z komunistami oraz zaakceptowanie postanowień jałtańskich. Mikołajczyk jednak, jako były premier rządu RP w Londynie, wicepremier Tymczasowego Rządu Jedności Narodowej, będący symbolem walki z narzuconym Polsce komunizmem, cieszył się poważaniem wśród polityków zachodnich. Znaczne poparcie miał także w środowisku emigracyjnym, szczególnie we Francji i Stanach Zjednoczonych.

Prezes Polskiego Stronnictwa Ludowego (PSL) po przyjeździe do Londynu zastał emigracyjne ugrupowania polityczne podzielone na dwa główne ośrodki. Miało to związek z kryzysem prezydenckim, do którego doprowadziło mianowanie przez prezydenta Władysława Raczkiewicza na swojego następcę Augusta Zaleskiego, w miejsce wyznaczonego w 1944 r. socjalisty Tomasza Arciszewskiego². Polska Partia Socjalistyczna (PPS), uznając nominację Zaleskiego za niezgodną z umową paryską z 1939 r., przeszła do opozycji wobec prezydenta, a także do powołanego przez niego rządu gen. Tadeusza Bora-Komorowskiego. PPS oraz Stronnictwo Demokratyczne (SD) wystąpiły z funkcjonującej od stycznia $1946 \mathrm{r}$. Rady Polskich Stronnictw Politycznych. Pozostały w niej jedynie ugrupowania uznające prezydenturę Zaleskiego: Stronnictwo Narodowe (SN), Stronnictwo Pracy (SP) - odłam kierowany przez gen. Józefa Hallera, oraz Stronnictwo Ludowe „Wolność”.

\section{Koncentracja Demokratyczna}

Ugrupowania przeciwne prezydenturze Zaleskiego postanowiły skoordynować swoje posunięcia poprzez utworzenie wspólnej platformy politycznej. 14 czerwca 1947 r. w Londynie przedstawiciele PPS, SD, Stronnictwa Pracy na Wychodźstwie (odłam SP kierowany przez Konrada Sieniewicza i Bronisława Sulimierskiego, właśc. Stefana Kaczorowskiego) oraz Polskiego Ruchu Wolnościowego „Niepodległość i Demokracja” (PRW „NiD”) powołali Koncentrację Demokratyczną ${ }^{3}$. Ugrupowania zrzeszone w Koncentracji Demokratycznej

Szerzej na temat stosunku polskich emigracyjnych ugrupowań politycznych do Stanisława Mikołajczyka po jego przybyciu do Wielkiej Brytanii: T. Wols za, Rząd RP na obczyźnie wobec wydarzeń w kraju 19451950, Warszawa 1998, s. 157-163.

2 Szerzej na temat kryzysu prezydenckiego: A. Friszke, Życie polityczne emigracji, Warszawa 1999, s. 71 74; A. Siwik, Polska Partia Socjalistyczna na emigracji w latach 1945-1956, Kraków 1998, s. 35-37; T. Wolsza, op. cit., s. 23-30; M. Kornat, Konstytucja za wszelka cenę. Prezydent RP na uchodźstwie August Zaleski (1947-1972), [w:] Prezydenci i Rzady RP na uchodźstwie 1939-1990. Wybrane problemy $z$ historii polskiej emigracji, red. H. Taborska, M. Fleming, A. Rzegocki, Londyn-Kraków 2013, s. 67-70; D. Gó re ck i, Polskie naczelne wtadze państwowe na uchodźstwie w latach 1939-1990, Warszawa 2002, s. 58-70.

3 A. Friszke, Adam Ciotkosz. Portret polskiego socjalisty, Warszawa 2011, s. 407. 
30 czerwca oglosiły swoją deklarację programową, będącą syntezą idei socjalistycznych, ludowych i chadeckich. Za naczelny cel uznano odtworzenie Polski wolnej, całej i demokratycznej. Stwierdzono, że odzyskanie niepodległości przez Polskę i wszystkie ujarzmione narody jest nierozerwalnie związane ze zwycięstwem demokracji na świecie. W deklaracji odrzucono możliwość powrotu do stosunków politycznych i społecznych sprzed września 1939 r. Zapowiedziano przywrócenie „prawdziwej treści” przeprowadzonym przez komunistów reformom: rolnej i nacjonalizacji kluczowych gałęzi przemysłu. Ugrupowaniom zrzeszonym w Koncentracji pozostawiono natomiast „swobodę pracy ideowej, wychowawczej i organizacyjnej zgodnie z ich własnymi programami reprezentującymi odrębne kierunki polityczne, a mianowicie: socjalistyczny, demokratyczno-społeczny i chrześcijańsko-społeczny”‘. Z Koncentracją współpracowało również opozycyjne wobec Mikołajczyka emigracyjne ugrupowanie ludowe - Stronnictwo Ludowe „Wolność”.

Koncentracja Demokratyczna okazała się jednak tworem efemerycznym, będącym raczej demonstracją sprzeciwu wobec zmian w polityce emigracyjnej związanej z nominacją Zaleskiego niż ciałem przejawiającym większą aktywność. Znaczące różnice występowały pomiędzy tworzącymi ją ugrupowaniami, jak również wewnątrz samych ugrupowań. Różnice te ujawniły się już podczas rozmów przedstawicieli Koncentracji z premierem Borem-Komorowskim w sprawie powołania rządu szerokiej koalicji. PRW „NiD” opowiadał się za porozumieniem z Zaleskim i wejściem do rządu Bora-Komorowskiego. PPS nie uznawała legalności nominacji Zaleskiego, natomiast Komitet Zagraniczny tej partii (przy sprzeciwie Adama i Lidii Ciołkoszów) akceptował przyjęcie z jego ręki teki premiera. Przeciwni kompromisom z obozem prezydenta Zaleskiego byli także reprezentanci Delegacji Zagranicznej PPS: Zygmunt Zaremba i Franciszek Białas5. Stronnictwo Pracy na Wychodźstwie w lutym 1948 r. poinformowało Wydział Wykonawczy Koncentracji Demokratycznej, że nie będzie uczestniczyć w rządzie bez PSL, a w którym przewidywany jest udział Komitetu Zagranicznego SP (grupa gen. Hallera). Chadecy podejrzewali PPS o próbę utworzenia bloku z SN i sanacją. Ostatecznie w kwietniu 1948 r. SP na Wychodźstwie wystąpiło z Koncentracji ${ }^{6}$. Brak aktywnej działalności Koncentracji krytykowało również SD, stojąc na stanowisku, że powinno dojść do porozumienia wszystkich „,zzeczywiście demokratycznych" stronnictw, mających odpowiedniki w kraju. Przewodniczący Komitetu Zagranicznego SD Stanisław Olszewski do takich stronnictw zaliczał PPS, PSL, SP i SD7. Jak widać,

4 Instytut Polski i Muzeum im. gen. Sikorskiego w Londynie [dalej: IPiMS], Kolekcja Stanisława Olszewskiego, Kol. 660/21, Deklaracja Koncentracji Demokratycznej, 30 VI 1947 r., b.p.

$5 \quad$ A. Siwik, op. cit., s. 42-43.

6 Biblioteka Uniwersytecka Katolickiego Uniwersytetu Lubelskiego Jana Pawła II [dalej: BU KUL], Rkps 2007, Pismo Zarządu na Wychodźstwie Stronnictwa Pracy do Wydziału Wykonawczego Koncentracji Demokratycznej [odpis], IV 1948 r. [brak daty dziennej], s. 230.

7 IPiMS, Kolekcja Tomasza Arciszewskiego, Kol.97/19, Notatka Stanisława Olszewskiego dot. Koncentracji Demokratycznej, 29 V 1948 r., b.p. 
zdaniem Olszewskiego przyszłe porozumienie nie miało obejmować partnera z Koncentracji Demokratycznej - PRW „NiD”.

Ugrupowania polityczne wchodzące w skład Koncentracji Demokratycznej były zainteresowane porozumieniem z Mikołajczykiem. Tylko wśród socjalistów występowały w tej kwestii rozbieżności. Przychylny stosunek do współpracy z ludowcami wyrażali Adam Ciołkosz i Zygmunt Zaremba, natomiast jej przeciwnikami byli Jan Kwapiński i Tomasz Arciszewski. Ciołkosz z Zarembą oraz przywódcy PRW „NiD” liczyli na włączenie PSL do struktury Koncentracji Demokratycznej. W Londynie miały miejsce nawet rozmowy przedstawicieli PPS (Adam Ciołkosz), PRW „NiD” (Jerzy Szyszko-Bohusz) i PSL (Franciszek Wilk) dotyczące poszerzenia Koncentracji ${ }^{8}$. Zakończyły się one niepowodzeniem, gdyż Mikołajczyk liczył na stworzenie własnego ośrodka politycznego i zależało mu bardziej na osłabieniu Koncentracji niż na wejściu do tego gremium. Ludowcy uważali zresztą Koncentrację za twór skompromitowany rozmowami z prezydentem Zaleskim i walką o stanowiska rządowe. Przywódca ludowców w Wielkiej Brytanii Franciszek Wilk w liście do Prezydium PSL przekazał następującą opinię o tym gremium:

Koncentracja [Demokratyczna], powołana do rozgrywki z Zaleskim i jego rządem Bora, nie osiągnęła swego celu, przeciwnie - skompromitowała się przewlekłymi negocjacjami z Zaleskim i w ten sposób przyczyniła się do ugruntowania jego «legalizmu» w opinii uchodźstwa. Rozmowy te toczyły się bowiem z nim jako z prezydentem. W rozmowach tych Koncentracja [Demokratyczna] zagubiła demokratyczne zasady, a unaoczniła wszystkim, iż chodzi jej o dostanie się do «żłobu», do resztek funduszów publicznych i tek ministerialnych, jeśli one jeszcze jakiś walor w oczach londyńskich Polaków posiadają9.

Wilk przekonywał także przebywających w Stanach Zjednoczonych przywódców PSL, że socjaliści traktują Koncentrację jako element taktycznej rozgrywki z prezydentem Zaleskim oraz z ludowcami i dlatego w interesie PSL leży osłabienie Koncentracji Demokratycznej.

\section{Rozmowy w sprawie powołania nowego ośrodka politycznego}

Po krótkim pobycie w Londynie Stanisław Mikołajczyk wraz z Kazimierzem Bagińskim i Stefanem Korbońskim wyjechali do Stanów Zjednoczonych, korzystając z zaproszenia

8 S. Łukasi ew ic z, Partia w warunkach emigracji. Dylematy Polskiego Ruchu Wolnościowego „Niepodlegtość i Demokracja" 1945-1994, Lublin-Warszawa 2014, s. 350-351.

9 Archiwum Instytutu Hoovera, sygn. 800/22/0/-/85, Dokumenty Stanisława Mikołajczyka, List Franciszka Wilka do Prezydium PSL w Waszyngtonie, 14 IV 1948 r., [cyt. za:] https://www.szukajwarchiwach.pl, skan 94-95. 
byłego ambasadora amerykańskiego w Warszawie Arthura Bliss Lane’a. W Stanach Zjednoczonych ludowcy byli przyjmowani w Departamencie Stanu i Kongresie. Doszło do spotkania z prezydentem Harrym Trumanem. Liderzy PSL prowadzili odczyty w wielu miastach, udzielali wywiadów, uczestniczyli w bankietach i zgromadzeniach. Dużym sukcesem politycznym Mikołajczyka było zawarcie umowy o współpracy między PSL a Kongresem Polonii Amerykańskiej (KPA). Porozumienie to było wynikiem dwudniowych (15-16 grudnia 1947 r.) rozmów przedstawicieli KPA z Prezydium PSL w Chicago. Ustalono, że akcja PSL w środowisku polonijnym będzie odbywać się w porozumieniu z KPA. Dzięki umowie ludowcy uzyskali dostęp do prasy polonijnej i aparatu organizacyjnego do prowadzenia działalności propagandowej na rzecz Polski ${ }^{10}$.

Praktycznie od początku pobytu władz PSL w Stanach Zjednoczonych podjęto rozmowy z przebywającymi tam socjalistami, głównie z Feliksem Grossem i Alojzym Adamczykiem. Byli oni zwolennikami współdziałania z PSL, do czego wzywali także Ciołkosza i Zarembę. Podczas rozmów ludowcy potwierdzili wolę bliskiej współpracy z PPS poszerzonej o SP Karola Popiela, akcentując przy tym swój krytyczny stosunek wobec ciągłości prawnej państwa opartej na konstytucji z kwietnia 1935 r. Rozmowom w sprawie współdziałania obydwu ugrupowań nie zaszkodziła nawet potępiająca Mikołajczyka uchwała Komitetu Zagranicznego PPS z 5 grudnia 1947 r., w której zarzucono Mikołajczykowi przyjęcie postanowień jałtańskich, co wyrządziło sprawie polskiej niepowetowane szkody ${ }^{11}$.

24-30 maja 1948 r. w Pont-à-Lesse w Belgii odbył się I zjazd PPS na uchodźstwie. Uwypuklił on podział istniejący w szeregach socjalistów w kwestii dalszej aktywności politycznej wśród emigracji. Przyjęte uchwały nakładały na PPS obowiązek podjęcia starań o odbudowę ciągłości państwowości polskiej, wskazując, że partia zamierza stać na gruncie legalizmu. Natomiast niewątpliwym sukcesem Zaremby i Ciołkosza było przyjęcie zapisów dotyczących dążenia do zjednoczenia obozu demokratycznego, w drodze porozumienia programowego między ruchem robotniczym i chłopskim ${ }^{12}$.

Wkrótce po zjeździe inicjatywę prowadzenia ofensywy politycznej podją Zaremba. Wobec odrzucenia przez prezesa Centralnego Komitetu Zagranicznego PPS Tomasza Arciszewskiego jego propozycji rozpoczęcia rozmów z PSL Zaremba podjął próbę osiągnięcia porozumienia z ludowcami w drodze rozmów prywatnych. Okazją do tego był przyjazd Mikołajczyka do Europy w drugiej połowie czerwca 1948 r. Do porozumienia z PPS i SP wzywali także pozostali członkowie Prezydium PSL - Bagiński i Korboński. Ludowcy proponowali powołanie komitetu narodowego, którego trzon stanowić miało

10 Mikotajczyk z Kongresem Polonii, „Dziennik Związkowy (Zgoda)” 1947, nr 296, s. 1; P. Stan ek, Stefan Korboński (1901-1989). Dziatalnośćpolityczna i spoteczna, Warszawa 2014, s. 134-135.

11 A. Friszke, Adam Ciotkosz..., s. 416-417.

12 Szerzej na temat I zjazdu PPS na uchodźstwie: A. Si iwik, op. cit., s. 72-84. 
porozumienie PSL z PPS. Do komitetu miały wejść także SN i SP, co doprowadziłoby do odtworzenia koalicji tych partii z okresu wojny.

Za porozumieniem z PSL i PPS opowiadali się chadecy Karola Popiela. Podczas posiedzenia Prezydium SP odbywającego się 2-3 czerwca 1948 r. ustalono, że priorytetem jest doprowadzenie do porozumienia trzech ,wielkich krajowych stronnictw” - SP, PSL i PPS. Uznano, że kwestie legalizmu czy sformowania komitetu narodowego są zagadnieniami wtórnymi, do ustalenia pomiędzy stronnictwami w późniejszym czasie. Jako przeciwników politycznych wskazano $\mathrm{SN}$ oraz $\mathrm{NiD}^{13}$.

Podczas posiedzenia Prezydium SP 17 lipca $1948 \mathrm{r}$. Popiel poinformował zebranych, iż podczas rozmów Mikołajczyka w Departamencie Stanu USA prezesowi PSL dano do zrozumienia, że nie przewiduje się możliwości ponownego uznania rządu londyńskiego. Dla Departamentu Stanu oraz brytyjskiego Foreign Office reprezentatywni mają być ,jedynie ci, których mandaty odświeżone zostały w Kraju po wojnie" ${ }^{14}$. Postanowiono przeprowadzić wstępne rozmowy z Mikołajczykiem oraz Zarembą. W rozmowach tych SP widziato dla siebie rolę mediatora pomiędzy PSL i PPS, dążącego do zbliżenia stanowisk tych ugrupowań.

Rozmowy pomiędzy PSL, PPS i SP prowadzono w Paryżu od 20 do 26 lipca. Socjalistów reprezentowali Zygmunt Zaremba i Franciszek Białas, PSL - Stanisław Mikołajczyk, Stanisław Kot i Franciszek Wilk, SP - Karol Popiel, Bronisław Sulimierski, Konrad Sieniewicz i Cyprian Odorkiewicz. Rozmowy paryskie nie przyniosły zbliżenia stanowisk pomiędzy PPS a PSL popieranym praz SP. Socjaliści przedstawili projekt deklaracji porozumienia stronnictw, uwzględniającej zasady legalizmu i ciągłości państwa na emigracji. Mikołajczyk natomiast wystąpił zdecydowanie przeciwko „tzw. legalizmowi londyńskiemu" i uznaniu konstytucji z kwietnia 1935 r.

Dalsze rozmowy kontynuowano w Londynie, gdzie Mikołajczyk dwukrotnie spotkał się z Ciołkoszem. Wynik tych negocjacji był odmienny od rezultatu rozmów paryskich. Zgodzono się, że podstawą przyszłego porozumienia nie powinna być konstytucja kwietniowa, a przy tworzeniu wspólnego ciała politycznego należy pominąć sanację, endecję i „kamarylę wojskową”. Porozumienie miało objąć trzy ugrupowania: PSL, PPS i SP. Zgodnie z sugestią Mikołajczyka Ciołkosz zaakceptował pominięcie PRW „NiD”, natomiast proponował dokooptowanie $\mathrm{SD}^{15}$.

W październiku 1948 r., po przybyciu do Londynu członków Prezydium PSL - Mikołajczyka, Korbońskiego i Bagińskiego, rozpoczęto pertraktacje z socjalistami i chadekami Popiela. 17 października powołano komisję (Bagiński, Zaremba, Sieniewicz), z zadaniem opracowania projektu porozumienia stronnictw oraz zasad wyjścia z kryzysu politycznego

13 BU KUL, Rkps 2009, Protokół nr 1 posiedzenia Prezydium SP z 2-3 VI 1948 r., s. 9-12.

14 Ibidem, Protokół nr 2 posiedzenia Prezydium SP z 17 VII 1948 r., s. 17.

15 A. Friszke, Adam Ciotkosz..., s. 456-457. 
na emigracji. Wypracowane projekty zakładały między innymi przyjęcie programu gospodarczego opartego na uchwałach Rady Jedności Narodowej (RJN) z kwietnia 1944 r., stworzenie porozumienia czterech stronnictw (PPS, PSL, SN i SP Popiela), powolanie RJN z przedstawicieli wymienionych ugrupowań oraz ewentualnie PRW „NiD” i SD. Przywódcy PPS, poza Kwapińskim, zaakceptowali opracowane projekty jako podstawę do dalszych rozmów. Natomiast Kwapiński na znak sprzeciwu zawiesił swój udział w pracach $\mathrm{CKZ}^{16}$.

\section{Deklaracja Porozumienia Stronnictw Demokratycznych}

15 listopada 1948 r. przedstawiciele PPS, PSL i SP podpisali w Londynie deklarację Porozumienia Stronnictw Demokratycznych (PSD). PSL reprezentowali Mikołajczyk, Bagiński i Korboński, w imieniu PPS podpisy złożyli Arciszewski, Białas, Ciołkosz, Pehr i Zaremba, natomiast SP - Popiel, Odorkiewicz i Sieniewicz ${ }^{17}$. Zawartego kompromisu nie poparł Kwapiński, który zgłosił swoje votum separatum.

W deklaracji podkreślono, że głównym celem stronnictw jest odzyskanie przez Polskę pełnej niepodległości i wprowadzenie w niej ustroju „,rzetelnej demokracji”. Poruszono sprawę uchwal jałtańskich (bez wymieniania tej nazwy) w odniesieniu do granic Polski, uznając, że narodu polskiego nie obowiązują , ,akty nowego zaboru ziem Rzeczypospolitej, dokonane przez obcych wbrew woli i bez zgody narodu polskiego" ${ }^{18}$. W kwestii granicy zachodniej stwierdzono, że do Polski muszą należeć odzyskane ziemie zachodnie po Odrę i Nysę Łużycką. Zdaniem autorów deklaracji Polska powinna uczestniczyć w organizowaniu się wolnych ludów Europy na zasadach federacyjnych oraz być członkiem międzynarodowych zrzeszeń politycznych i gospodarczych.

W przyszłej Polsce miał funkcjonować system wielopartyjny, z rządami opartymi na większości parlamentarnej, powoływanej na zasadach pięcioprzymiotnikowej ordynacji wyborczej. Wyłonione w wyniku wyborów przedstawicielstwo narodowe miało określić formy ustrojowe państwa i uchwalić demokratyczną konstytucję. W okresie przejściowym zamierzano powołać rząd odpowiedzialny przed reprezentacją polityczną, wyposażoną w „atrybuty inicjatywy, stanowienia i kontroli”. Zapewnione miały być: równość wszystkich wobec prawa, pełna wolność osobista i polityczna, wolność sumienia i przekonań, wolność słowa, zgromadzeń, zrzeszania się. Zapowiadano likwidację wszelkich instytucji

16 IPiMS, Kolekcja Tomasza Arciszewskiego, Kol. 97/26, List Jana Kwapińskiego do nieznanego działacza PPS, 3 XI 1948 r., b.p.

${ }_{17}$ Deklaracja Porozumienia Stronnictw Demokratycznych, Londyn 1948, s. 8; Deklaracja Porozumienia Stronnictw Demokratycznych, ,Jutro Polski” 1948, nr 21 (145), s. 1-2.

18 Deklaracja Porozumienia Stronnictw Demokratycznych, Londyn 1948, s. 5. 
będących narzędziami komunistycznego ucisku oraz ukaranie sprawców zbrodni popełnionych na narodzie polskim ${ }^{19}$.

Zapisy deklaracji dotyczące spraw społeczno-ekonomicznych nosily charakter jednoznacznie lewicowy. Państwo miało dbać o interesy ludzi pracy, zlikwidować wyzysk, troszczyć się o sprawiedliwy podział dochodu społecznego oraz podnoszenie poziomu życia obywateli. Na straży praw socjalnych miały stać całkowicie niezależne związki zawodowe. Deklarowano uspołecznienie kluczowych gałęzi przemysłu, źródeł energii, banków, środków komunikacji i transportu. W rękach prywatnych miały pozostać przemysł średni i drobny oraz rzemiosło.

Duża część deklaracji dotyczyła ustroju rolnego, który miał być oparty na samodzielnych, jednorodzinnych gospodarstwach chłopskich, stanowiących indywidualną własność. Zapowiadano przeprowadzenie reformy rolnej, która obejmie ziemie pozostające w rękach państwa i upełnorolni gospodarstwa karłowate. Porozumienie deklarowało usunięcie „szkodliwego gospodarczo i sprzecznego z psychiką chłopa” systemu kolektywizacji rolnictwa oraz odbudowę samorządu rolniczego.

Sygnatariusze podkreślili konieczność wprowadzenia samorządu terytorialnego, społeczno-gospodarczego, kulturalnego oraz przywrócenia spółdzielczości opartej na zasadach dobrowolności i pełnej samorządności.

W deklaracji wykorzystano także dorobek myśli chrześcijańskiej. Państwo miało udzielać pomocy i opieki (prawnej, społecznej, kulturalnej) rodzinie, będącej podstawową komórką społeczeństwa. Podstawę życia publicznego powinny stanowić zasady moralności i etyki chrześcijańskiej, a szczególnie tkwiący w tradycji chrześcijańskiej szacunek człowieka dla człowieka i umiłowanie wolności ${ }^{20}$.

Uzupełnieniem deklaracji był protokół poufny, zawierający zobowiązanie stron do wspólnego działania przynajmniej do czasu ukonstytuowania się Sejmu Konstytucyjnego w wolnej Polsce. Stronnictwa deklarowały również opracowanie projektu ordynacji wyborczej do Sejmu Konstytucyjnego i wyborów samorządowych, start w wyborach z własnymi listami i programami, przy zachowaniu wzajemnej życzliwości, uzgadnianie spraw dotyczących stosunków z krajem i opieki nad emigracją. Protokół zawierał także deklarację o niewchodzeniu w porozumienia indywidualne ze stronnictwami i ruchami politycznymi nieobjętymi porozumieniem, z wyjątkiem stowarzyszeń o charakterze międzynarodowym ${ }^{21}$.

Dla sygnatariuszy tego układu PSD stanowiło próbę nawiązania bliskiej współpracy ugrupowań centrolewicowych. Dodatkowym atutem porozumienia dla socjalistów było uniemożliwienie utworzenia przez Mikołajczyka komitetu narodowego ${ }^{22}$.

19 Ibidem.

20 Ibidem, s. 6-8.

21 A. Siwik, op. cit., s. 52-53.

22 IPiMS, Kolekcja Tomasza Arciszewskiego, Kol. 97/9 A, List Tomasza Arciszewskiego do Wacława Zborowskiego, 20 XII 1948 r., b.p. 
Porozumienie miało być wstępem do odbudowy czwórporozumienia z okresu okupacji. Prowadzono równolegle rozmowy z reprezentantami SN, które jednak nie przystąpiło do PSD. Przedstawiciele SN proponowali utworzenie w pierwszej kolejności Rady Narodowej, następnie rządu, a potem rozstrzygnięcie sprawy prezydentury.

Zawarcie porozumienia z PPS, do niedawna jednym z filarów obozu legalistycznego, stanowiło niewątpliwie duży sukces polityczny Mikołajczyka i Popiela. Powracali na emigracyjną scenę polityczną, nie rezygnując ze swojego stanowiska w ważnych dla nich kwestiach: stosunku do konstytucji czy legalizmu. Deklaracja PSD nie zawierała zapisów odnoszących się do ciągłości państwa polskiego na emigracji, jak również do bieżącej sytuacji politycznej panującej wśród emigracji polskiej. Członkowie PSL i SP jednoznacznie popierali alians z socjalistami.

Socjaliści dzięki porozumieniu z ludowcami i chadekami pokazali zdolność do współpracy z partnerami nienależącymi do obozu legalistycznego. Jednak wśród członków PPS było wielu przeciwników aliansu z ,jałtańczykami”. Przyczynił się do tego także Jan Kwapiński, rozsyłając do działaczy PPS listy zawierające krytykę zawartego porozumienia oraz informacje o zawieszeniu swojego udziału w pracach CKZ. Prezes CKZ PPS Tomasz Arciszewski otrzymywał listy od zdezorientowanych członków domagających się uzasadnienia podjętej decyzji politycznej. Niektórzy z nich w ostrych słowach krytykowali pakt z Mikołajczykiem. Arciszewski, odpowiadając na krytykę, podkreślał, że nie zawierano umowy z Mikołajczykiem, gdyż w skład PSD nie wchodzą poszczególne osoby, ale prezydia stronnictw. Pisał, że zawarte porozumienie jest próbą odbudowy sojuszu robotniczo-chłopskiego, a zarazem wstępem do dalszej konsolidacji stronnictw emigracyjnych ${ }^{23}$.

Prasa emigracyjna związana z obozem legalistycznym krytycznie odniosła się do zawartego porozumienia oraz poszczególnych zapisów deklaracji PSD. Krytyka nasiliła się po wystąpieniu Mikołajczyka podczas II zjazdu PSL we Francji 20 listopada 1948 r., w którym bronił swojej polityki z lat 1945-1947, odrzucając legalizm i konstytucję z 1935 r. Uchwałę krytykującą sformułowania deklaracji PSD za brak nawiązania do traktatu ryskiego oraz pominięcie kwestii legalizmu władz polskich przyjęty 3 grudnia 1948 r. Związki Ziem Wschodnich RP24.

Wpływ na przyspieszenie tempa negocjacji związanych $z$ tworzeniem odrębnego ośrodka politycznego miały także czynniki zewnętrzne. Rozpoczęta w czerwcu $1948 \mathrm{r}$. blokada zachodnich sektorów Berlina doprowadziła do eskalacji napięcia pomiędzy ZSRR a państwami zachodnimi. Politycy emigracyjni przewidywali możliwość wybuchu konfliktu zbrojnego, dlatego dążyli do powołania ośrodka politycznego, będącego partnerem do

23 Ibidem, List Tomasza Arciszewskiego do Jerzego Gawendy, 6 XII 1948 r.; List Tomasza Arciszewskiego do Wacława Zborowskiego, 20 XII 1948 r., b.p.

24 Uchwata Związów Ziem Wschodnich RP, „Lwów i Wilno” 1948, nr 96, s. 1. 
rozmów dla polityków zachodnich. Ponadto zagrożenie ekspansją komunizmu skłoniło Departament Stanu USA do nawiązywania kontaktów z przedstawicielami emigracji, reprezentującymi główne nurty polityczne.

\section{Działalność PSD}

Pracami PSD miała kierować Komisja Porozumiewawcza Stronnictw Demokratycznych, do której weszło po trzech przedstawicieli stronnictw założycielskich. Powołano także Sekretariat z siedzibą w Londynie, będący organem wykonawczym PSD ${ }^{25}$. Do zadań Sekretariatu należało zwoływanie i organizowanie sesji Komisji Porozumiewawczej, a w okresie między sesjami (za zgodą prezydiów stronnictw) powoływanie podkomisji dla realizacji określonych zadań. Członkami tego gremium zostali Bagiński, Ciołkosz i Sieniewicz. Kazimierz Bagiński wziął udział jedynie w pierwszym posiedzeniu Sekretariatu, następnie wyjechał do Stanów Zjednoczonych, gdzie mieszkał. Jego miejsce w Sekretariacie zajął Franciszek Wilk ${ }^{26}$. Pracę Sekretariatu utrudniał pobyt władz PSL w Stanach Zjednoczonych, wpływając również na pozycję ludowców wobec partnerów z PSD.

Podczas pierwszego posiedzenia Sekretariatu 17 listopada 1948 r. zadecydowano o utworzeniu grupy polskiej federalnego ruchu europejskiego oraz podkomisji do zagadnień opieki nad emigracją. Postanowiono także rozpocząć prace nad projektami konstytucji i ordynacji wyborczych do sejmu oraz do organów samorządowych ${ }^{27}$.

Podkomisję dla spraw Emigracyjnych z siedzibą w Paryżu powołał Sekretariat 30 grudnia 1948 r. Jej członkami zostali przedstawiciele trzech ugrupowań: Franciszek Białas z PPS, Cyprian Odorkiewicz reprezentujący SP oraz Wacław Soroka z PSL. Uzgodniono również utworzenie podkomisji dla obrony granicy na Odrze i Nysie Łużyckiej wobec zachodniej opinii publicznej. Za jej działania na gruncie amerykańskim odpowiadał PSL, natomiast PPS powierzono odpowiedzialność za teren Wielkiej Brytanii. Podczas posiedzenia Sekretariatu 30 grudnia 1948 r. zaaprobowano także wniosek PSL o opracowanie memoriału do ONZ poświęconego sytuacji w Polsce ${ }^{28}$.

W styczniu 1949 r. Sekretariat PSD upoważnił udającego się do Paryża Sieniewicza do zwołania inauguracyjnego posiedzenia Podkomisji dla spraw Emigracyjnych. Posiedzenie

25 Archiwum Zakładu Historii Ruchu Ludowego [dalej cyt.: AZHRL], Polskie Stronnictwo Ludowe na Uchodźstwie [dalej cyt.: PSL na U], sygn. 183, Komunikat Porozumienia Stronnictw Demokratycznych, 15 XI 1948 r., b.p.

26 A. Friszke, Adam Ciotkosz..., s. 460. W lipcu 1949 r. Bagińskiego zastąpił w Sekretariacie PSD Stanisław Wójcik.

27 AZHRL, PSL na U, sygn. 183, Protokół nr 1 posiedzenia Sekretariatu PSD z 17 XI 1948 r., b.p.

28 Archiwum Polskiego Instytutu Naukowego w Ameryce [dalej: APIN], Kolekcja Karola Popiela, Kol. 9/45, Protokół nr 3 posiedzenia Sekretariatu PSD z 30 XII 1948 r., b.p. 
się jednak nie odbyło, gdyż Franciszek Białas odmówił udziału w pracach podkomisji, uznając, że Sekretariat nie miał uprawnień do jej powołania ${ }^{29}$. Wprawdzie w lutym $1949 \mathrm{r}$. Białasa jako przedstawiciela PPS zastąpił Lucjan Krawiec, jednak podkomisja nadal nie rozpoczęła funkcjonowania. Nie odnaleziono dokumentów wskazujących na podjęcie jakiejkolwiek działalności przez wspomnianą podkomisję. Kwestia funkcjonowania Podkomisji dla spraw Emigracyjnych stanowiła pierwszy istotny rozdźwięk pomiędzy sygnatariuszami deklaracji PSD.

Kolejnym testem na zdolność współdziałania ugrupowań tworzących PSD była sprawa wyboru delegatów na posiedzenie Rady Międzynarodowej Unii Europejskiej (RMUE), stanowiącej w założeniu jej inicjatorów parlament europejkki. Politycy popierający idee ruchu europejskiego ustalili termin inauguracyjnego posiedzenia RMUE na koniec lutego 1949 r., zapraszając na nie także Polaków. W styczniu 1949 r. rozpoczęły się rozmowy PSD z innymi ugrupowaniami w celu wyboru Rady Polskiej Unii Europejskiej. Podczas posiedzenia Sekretariatu 20 stycznia 1949 r. uzgodniono zasady powołania Rady Polskiej, przewidując w niej miejsca także dla innych ugrupowań. W skład rady miało wejść po 12 przedstawicieli najważniejszych ugrupowań: tj. SN, PPS, PSL i SP, czterech przedstawicieli $\mathrm{NiD}$ oraz trzech SD. Dodatkowo w radzie miało zasiadać 17 osób bezpartyjnych. Do grona prezesów honorowych rady zaproponowano Tomasza Arciszewskiego, Stanisława Mikołajczyka, Karola Popiela i Helenę Sikorską. Jedno miejsce przewidziano również dla przedstawiciela SN. Przewodniczącym Komitetu Wykonawczego miał zastać Adam Ciołkosz, wiceprzewodniczącymi - Stefan Glaser i przedstawiciel SN, sekretarzem - Franciszek Wilk. Ciołkosza z Glaserem wytypowano także jako delegatów na posiedzenie Rady Międzynarodowej Unii Europejskiej ${ }^{30}$.

Proponowanego podziału miejsc nie zaakceptowało SN, domagając się przyznania Komitetowi Zagranicznemu SP połowy z 12 miejsc przewidzianych dla SP. Endecy kwestionowali również obecność prof. Kota na liście członków rady z ramienia PSL. Pomimo braku porozumienia z SN postanowiono przystąpić do formowania Rady Polskiej. 2 lutego 1949 r. odbyło się zebranie osób zaproszonych do jej tworzenia. Jednak ze względu na występujące różnice zdań udało się powołać jedynie Komisję Organizacyjną Rady Polskiej Unii Europejskiej, złożoną wyłącznie z przedstawicieli PPS, SP, NiD pod przewodnictwem Edwarda Raczyńskiego ${ }^{31}$. Zgodnie z przewidywaniami komisja w takim składzie nie była w stanie wyłonić Rady Polskiej.

Inicjatywę ponownie przejął Sekretariat PSD, proponując wystąpienie do Sekretariatu Unii Europejskiej z ofertą wysłania do Brukseli Ciołkosza i Glasera, w charakterze

29 AZHRL, PSL na U, sygn. 183, Notatka z posiedzenia Sekretariatu PSD z 20 I 1949 r., b.p.

30 APIN, Kolekcja Karola Popiela, Kol. 9/45, Protokół nr 5 posiedzenia Sekretariatu PSD z 20 I 1949 r., b.p.

31 Archiwum Instytutu Hoovera, sygn. 800/22/0/-/111, Dokumenty Stanisława Mikołajczyka, Przebieg rozmów w sprawie utworzenia Polskiej Rady Unii Europejskiej, 5 II 1949 r., [cyt. za:] https://www. szukajwarchiwach.pl, skan 659. 
delegatów PSD, reprezentującego „przygniatającą większość społeczeństwa polskiego w Kraju"32.

Projekt Sekretariatu nie uzyskał akceptacji Prezydium PPS. Socjaliści zaproponowali natomiast utworzenie Komisji Organizacyjnej Rady Polskiej bez reprezentantów SP i KZ SP. Sieniewicz w imieniu SP stanowczo zaoponował przeciwko tej koncepcji, uznając, że propozycja PPS jest sprzeczna z umową stronnictw z 15 listopada 1948 r. Projektu PPS wykluczającego partnera nie poparli także ludowcy. W ocenie Franciszka Wilka intencją PPS było osłabienie ludowców poprzez wyeliminowanie z porozumienia sprzyjającego im SP: „W całej tej sprawie chodzi bowiem o utrącenie Stron[nictwa] Pracy jako partnera porozumienia związanego z nami, i to zarówno socjalistom i endekom, chodzi też o personalne utrącanie przez jednych i drugich p. Karola Popiela, głównie jako przeciwnika «legalizmu» w porozumieniu" ${ }^{33}$.

Ostatecznie na sugestię prezesa Międzynarodowego Komitetu Wykonawczego Ruchu Europejskiego Duncana Sandysa do Brukseli pojechali Ciołkosz i Raczyński, z poparciem PSD, KZ SP i SD.

Rozmowy w sprawie powołania Rady Polskiej i wyboru delegatów na posiedzenie RMUE ukazały duże rozbieżności wśród stronnictw PSD. Ugrupowania wchodzące w jego skład nie potrafily się porozumieć w zasadniczych kwestiach. Oprócz różnic w sprawach legalizmu i konstytucji kwietniowej duże znaczenie miały także ambicje osobiste, wzajemna nieufność oraz animozje pomiędzy liderem PSL a przywódcami PPS (Arciszewski, Kwapiński). Współpracy ugrupowań w ramach PSD nie sprzyjało także postępowanie SN, dążącego do skonfliktowania stronnictw tworzących PSD.

Arciszewskiemu zależało na włączeniu SN do współpracy przy tworzeniu Rady Polskiej, a następnie na płaszczyźnie PSD. Gdy współdziałanie z SN w sprawie Rady okazało się niemożliwe, poddał ostrej krytyce dotychczasową działalność PSD. Podczas konferencji tworzących go stronnictw 19 lutego 1949 r. stwierdził, że PSD musi zacząć rozwiązywać problemy występujące wśród emigracji, gdyż jak dotąd nic nie zrobiło w tej kwestii:

Nie rozwiązaliśmy dotąd żadnego zagadnienia, ani kwestii legalizmu, ani nie wciągnęliśmy SN w orbitę Porozumienia, co postawiliśmy sobie za cel, a ciągle jesteśmy tylko atakowani ze wszystkich stron. Musimy jakoś te rzeczy w przyszłości uporządkować, jeśli chodzi o zagadnienia emigracyjne i sprawę rządu. To, co dotąd mamy, to program na Kraj, który po powrocie będziemy realizować, nic nie mamy uzgodnionego i przygotowanego na dziś, na emigracji i nic w tej dziedzinie nie robimy ${ }^{34}$.

32 APIN, Kolekcja Karola Popiela, Kol. 9/45, Protokół nr 10 posiedzenia Sekretariatu PSD, luty 1949 r. [brak daty dziennej], b.p.

33 Archiwum Instytutu Hoovera, sygn. 800/22/0/-/85, Dokumenty Stanisława Mikołajczyka, List Franciszka Wilka do Prezydium PSL w Waszyngtonie (odpis), luty 1949 r. [brak daty dziennej], [cyt. za:] https://www.szukajwarchiwach.pl, skan 312.

34 Ibidem, 111, Notatka z konferencji stronnictw PSD, 19 II 1949 r., skan 629. 
Słabość PSD, niewielką skuteczność działań jego Sekretariatu i brak współpracy ugrupowań dostrzegali także ludowcy. Franciszek Wilk winą za to obciążał socjalistów, a przede wszystkim Arciszewskiego:

Staje się on [Sekretariat PSD - R.W.] w praktyce instytucją bez większego znaczenia. Cokolwiek się postanowi, Prezydium PPS wywraca. Jest to po prostu strata czasu. Dotąd nic konkretnego się nie załatwiło ani żaden plan Sekretariatu porozumienia nie uzyskał akceptacji PPS. Nie sądzę, by to była tylko wina Ciołkosza. Arciszewski, niestety, ciąży bardzo na taktyce PPS, a kto go nakręca, trudno powiedzieć. Chodzi o to, «kto» z sanacji, gdyż wskazuje uległość w tym kierunku coraz większą. W stosunku do Stron[nictwa] Pracy występuje coraz bardziej agresywnie. Kocha KZ SP, bo przecież byli w jego rządzie ${ }^{35}$.

Jedną z niewielu kwestii niebudzących kontrowersji w PSD był negatywny stosunek do III Rady Narodowej (RN) powołanej przez prezydenta Zaleskiego 3 maja 1949 r. Jej członkami zostali przedstawiciele piłsudczykowskiej Ligi Niepodległości Polski, Stronnictwa Ludowego „Wolność” i Komitetu Zagranicznego Stronnictwa Pracy. Miejsca w Radzie otrzymało także 15 bezpartyjnych. Premier Tadeusz Tomaszewski zaprosił do uczestnictwa w RN również inne stronnictwa niepodległościowe, dotychczas niebędące w niej reprezentowane. Socjaliści, którzy nie uznawali Zaleskiego za prezydenta, nie mogli z jego rąk przyjąć mandatów. Natomiast zaproszenie do uczestnictwa w RN nie obejmowało PSL i SP Popiela.

Członkowie Sekretariatu PSD uzgodnili tekst wspólnego stanowiska dotyczącego Rady Narodowej podczas posiedzeń 14-16 maja ${ }^{36}$. W opublikowanym komunikacie zdyskredytowano Radę jako organ niereprezentatywny, pozbawiony przedstawicieli polskich stronnictw politycznych, powołany w sposób niedemokratyczny. Zaznaczono, że stronnictwa tworzące PSD nie wezmą udziału w „tak zwanej Radzie Narodowej”. Zapowiedziano przy tym podjęcie działań zmierzających do utworzenia „polskiej reprezentacji narodowej i państwowej”, reprezentującej kierunki polityczne wyrażające opinię społeczeństwa polskiego, z wykluczeniem organizacji „totalistycznych" ${ }^{77}$. Pomimo negatywnego stosunku do powołanej RN treść komunikatu spotkała się z krytyką niektórych członków władz PPS. Tomasz Arciszewski uznał go za niepotrzebny, twierdząc przy tym, że jego zdaniem działalność Sekretariatu PSD jest zawieszona. Krytycznie do komunikatu odniósł się również Franciszek Białas, uznając, że Sekretariat, wydając go, przekroczył swoje kompetencje.

35 Archiwum Instytutu Hoovera, sygn. 800/22/0/-/85, Dokumenty Stanisława Mikołajczyka, List Franciszka Wilka do Prezydium PSL w Waszyngtonie (odpis), luty 1949 r. [brak daty dziennej], [cyt. za:] www.szukajwarchiwach.pl, skan 313.

36 APIN, Kolekcja Karola Popiela, Kol. 9/45, Protokół nr 13 posiedzenia Sekretariatu PSD z 14, 15, 16 V 1949 r., b.p.

37 Komunikat Sekretariatu PSD, „Jutro Polski” 1949, nr 10 (157), s. 1. 
W maju 1949 r. stronnictwa PSD podjęły również akcję dotyczącą uzyskania gwarancji zachodnich dla przebiegu granicy polsko-niemieckiej. W związku z zaplanowaną na czerwiec 1949 r. konferencją ministrów spraw zagranicznych czterech mocarstw w Paryżu PSL zasugerowało złożenie w Departamencie Stanu USA, brytyjskim Foreign Office i Ministerstwie Spraw Zagranicznych Francji memoriałów w sprawie polskiej granicy zachodniej. Memoriał dotyczący granicy polsko-niemieckiej 18 maja 1949 r. doręczono do Foreign Office ${ }^{38}$. Z kolei w Stanach Zjednoczonych z inicjatywy PSD grupa kongresmenów polskiego pochodzenia interweniowała $\mathrm{w}$ sprawie granicy zachodniej u sekretarza stanu Deana Achesona ${ }^{39}$.

Działalność Sekretariatu PSD poddano ocenie podczas posiedzeń Komisji Porozumiewawczej Stronnictw Demokratycznych. Odbyły się one 18 i 20 lipca 1949 r. w Londynie, z udziałem liderów ugrupowań: Mikołajczyka, Arciszewskiego i Popiela. Pomimo głosów krytycznych, zarzucających Sekretariatowi przekraczanie swoich kompetencji (Białas) oraz zbyt małą aktywność (Popiel, Mikołajczyk), Komisja przyjęła do wiadomości sprawozdanie Sekretariatu ${ }^{40}$.

Podczas obrad Komisji doszło do polemiki pomiędzy ludowcami i przedstawicielami PPS, w związku z kwietniowymi uchwałami PSL. 27 kwietnia 1949 r. NKW PSL przyjął między innymi uchwałę stwierdzającą, że konstytucja z 1935 r. została bezprawnie narzucona narodowi, że jest wyrazem dyktatorskiego systemu rządzenia państwem i PSL odrzuca możliwość szerszego porozumienia na jej podstawie ${ }^{41}$. Arciszewski z Białasem uznali, że przyjęta uchwała stanowiła zaskoczenie dla PPS i zasadniczo zmieniła sytuację polityczną. W odpowiedzi Mikołajczyk stwierdził, iż nie można mówić o zaskoczeniu, ponieważ stanowisko PSL w kwestii legalizmu było od dawna znane partnerom z PSD i nie może być przeszkodą we współpracy. Z kolei Stanisław Wójcik zarzucił socjalistom pertraktacje finansowe z SN i PRW „NiD”, „które nie są zgodne z lojalnością wobec partnerów PSD”42. Mówił o zawartym 6 maja porozumieniu PPS, SN i PRW „NiD” z ppłk. Janem Kamieńskim, depozytariuszem Funduszu Krajowego pochodzącego z dotacji rządu amerykańskiego. Na mocy porozumienia komisja złożona z przedstawicieli trzech wymienionych ugrupowań podjęła się zabezpieczenia funduszu. Dzięki temu pod kontrolą trzech stronnictw znalazło się ponad milion dolarów ${ }^{43}$.

38 APIN, Kolekcja Karola Popiela, Kol. 9/45, Protokół nr 13 posiedzenia Sekretariatu PSD z 14, 15 i 16 V 1949 r., b.p.

39 AZHRL, PSL na U, sygn. 183, Protokół posiedzenia Komisji Porozumiewawczej Stronnictw Demokratycznych z 20 VII 1949 r., b.p.

40 Komunikat PSD, „Jutro Polski” 1949, nr 14 (161), s. 1.

$41 \quad$ R. Buczek, Stanistaw Mikotajczyk, t. 2, Toronto 1996, s. 195.

42 AZHRL, PSL na U, sygn. 183, Protokół posiedzenia Komisji Porozumiewawczej Stronnictw Demokratycznych z 20 VII 1949 r., b.p.

43 A. Friszke, Życie polityczne emigracji..., s. 114-115. 
Krytyka ze strony socjalistów zirytowała Mikołajczyka, który podczas posiedzenia w dniu 20 lipca poprosił o jednoznaczną odpowiedź na pytanie o możliwość dalszej współpracy przy istniejących różnicach poglądów w kwestii legalizmu. $\mathrm{Z}$ treści zachowanego protokołu z wymienionego posiedzenia nie wynika, aby ją uzyskał.

\section{Próby rozszerzenia składu PSD}

Podczas pierwszego posiedzenia Sekretariatu 17 listopada 1948 r. postanowiono podjąć rozmowy z przedstawicielami SN, SD oraz PRW „NiD” w celu poszerzenia składu Porozumienia. 7 grudnia do SD oraz PRW „NiD” wystosowano pisma zapraszające do podjęcia dyskusji na temat założeń programowych i politycznych PSD, celem ewentualnego przystąpienia tych ugrupowań do Porozumienia ${ }^{44} .30$ grudnia w trakcie posiedzenia Sekretariatu doszło do rozmów z przedstawicielami SD: Stanisławem Olszewskim, Andrzejem Rosnerem i Zygmuntem Hoffmanem. Wyrazili oni swój pozytywny stosunek do deklaracji porozumienia z 15 listopada i potwierdzili chęć przystąpienia do PSD ${ }^{45}$.

Opóźniło się natomiast rozpoczęcie rozmów z PRW „NiD”, gdyż organizacja ta nie przedstawiała Sekretariatowi statutu oraz wykazu władz. 11 maja 1949 r. odbyło się spotkanie Sekretariatu z reprezentantami PRW „NiD”: Janem Nowakiem, Jerzym Szyszko -Bohuszem i Bolesławem Wierzbiańskim. W trakcie zebrania strony przedstawiły stanowiska w kwestiach politycznych. Przedstawiciele „NiD” oświadczyli, że zajmują stanowisko „niepodległościowe”, uznają ciągłość państwa polskiego na emigracji oraz Augusta Zaleskiego za prezydenta RP, chociaż są do niego w opozycji. Zadeklarowali także pisemne ustosunkowanie się do kwestii przystąpienia do $\mathrm{PSD}^{46}$.

Wobec braku zgłoszenia ze strony PRW „NiD” podczas posiedzenia Sekretariatu 15 lipca 1949 r. jednomyślnie postanowiono przygotować wniosek o przyjęcie jedynie SD do struktur Porozumienia.

Kwestia zasad rozszerzenia PSD uległa zmianie w wyniku posiedzenia Komisji Porozumiewawczej Stronnictw Demokratycznych 20 lipca 1949 r. Franciszek Białas w imieniu PPS stwierdził, że wprowadzenie SD do porozumienia jest słuszne, ale tylko łącznie z grupą PRW „NiD”. Zaproponował odroczenie przyjęcia wniosku SD i ponowne wystąpienie do PRW „NiD” o odpowiedź na złożoną propozycję. Liderom PPS nie zależało na poszerzeniu PSD jedynie o SD, które nie przedstawiało większej siły na politycznej scenie emigracyjnej. Ponadto obawiali się, że przyjęcie SD wzmocni pozycję ludowców w ramach

44 AZHRL, PSL na U, sygn. 183, Protokół nr 2 posiedzenia Sekretariatu PSD z 20 XII 1948 r., b.p.

45 Studium Polski Podziemnej w Londynie [dalej: SPP], Kolekcja Adama Ciołkosza, Kol. 133/406, Dodatek do protokołu posiedzenia Sekretariatu PSD z przedstawicielami KZ SD z 30 XII 1948 r., b.p.

46 APIN, Kolekcja Karola Popiela, Kol. 9/45, Protokół nr 12 posiedzenia Sekretariatu PSD z 11 V 1949 r., b.p. 
PSD, tym bardziej że działania PSL popierało już SP Popiela. Natomiast ludowcy nie byli zwolennikami akcesji PRW „NiD”, które było ugrupowaniem niemającym odpowiednika w kraju, niebędącym członkiem RJN. Wydaje się, że istotę zastrzeżeń PSL wobec PRW „NiD” wyraził Stanisław Wójcik: „Przyjęcie NiD-u utworzyłoby kanał, przez który sanacja wśliznęłaby się do PSD” ${ }^{47}$. Przedstawiciele PPS przeforsowali jednak swoje stanowisko i postanowiono odroczyć przyjęcie SD oraz ponownie wystąpić do PRW „NiD”.

Ostatecznie SD zostało przyjęte do PSD dopiero w październiku 1949 r., natomiast PRW „NiD”, obawiając się przekształcenia PSD w komitet narodowy uzurpujący sobie prawo do roli rządu, nie wszedł do PSD, wybierając utworzoną w grudniu 1949 r. Radę Polityczną.

Najdłużej trwały negocjacje ze Stronnictwem Narodowym. Ugrupowaniom tworzącym PSD zależało na włączeniu dysponującego dużym potencjałem na emigracji SN do porozumienia. Zasadniczym problemem było tu stanowisko $S N$ w sprawie uznania konstytucji z kwietnia 1935 r., którą niezmiennie odrzucał Mikołajczyk. W styczniu i lutym 1949 r. z Bieleckim parokrotnie spotkał się Arciszewski. Jego zdaniem prezes SN pozytywnie wypowiadał się na temat deklaracji z 15 listopada, natomiast oczekiwał publicznego oświadczenia Mikołajczyka w sprawie ciągłości prawnej państwowości polskiej i granic wschodnich.

Podczas pobytu Bieleckiego w Waszyngtonie w lutym 1949 r. miały miejsce jego rozmowy z Prezydium PSL (Mikołajczyk, Korboński, Bagiński) oraz z prezesem Rady PPS Zarembą. Polityk PPS bardzo pozytywnie oceniał ich rezultat. Twierdził, że doszło do znacznego zbliżenia stanowisk, Mikołajczyk porzucił koncepcje komitetową (co „zespoliło go ściślej” z Korbońskim i Bagińskim). Na koniec maja lub początek czerwca zaplanowano spotkanie, na którym miano podsumować rozmowy waszyngtońskie i utworzyć ewentualnie czwórporozumienie ${ }^{48}$.

Wśród liderów PSL występowały znaczne różnice zdań w kwestii miejsca Stronnictwa na emigracyjnej scenie politycznej. W przeciwieństwie do Mikołajczyka, Korboński z Bagińskim nie byli przeciwnikami współpracy PSL z „polskim” Londynem, uznania ważności konstytucji kwietniowej. W grudniu 1948 r. Korboński udzielił wywiadu dla „Nowego Świata”, w którym komplementował emigracyjnych przywódców, między innymi Tomasza Arciszewskiego i gen. Władysława Andersa, uznał też ważną rolę legalizmu w dążeniu do osiągnięcia porozumienia wśród emigracji ${ }^{49}$. Korboński z Bagińskim, wykorzystując

47 AZHRL, PSL na U, sygn. 183, Protokół posiedzenia Komisji Porozumiewawczej Stronnictw Demokratycznych z 20 VII 1949 r., b.p.

48 List Zygmunta Zaremby do CKZ PPS w Londynie, 15 III 1949 r., [w:] Zygmunt Zaremba, Listy: 1946-1967, oprac. O. Blaton, A. Friszke, Warszawa 2000, s. 276-278; IPiMS, Kolekcja Tomasza Arciszewskiego, Kol. 97/9 B, List Tomasza Arciszewskiego do Władysława Zachariasiewicza, 24 III 1949 r., b.p.; List Zygmunta Zaremby do Stefana Korbońskiego, 4 V 1949 r., [w:] Zygmunt Zaremba, Listy: 1946-1967, s. 279-281.

49 P. Stanek, op. cit., s. 137. 
własną przewagę w Prezydium PSL, usiłowali usuwać z władz stronnictwa przeciwników swoich koncepcji ${ }^{50}$. Mikołajczyk, chcąc zapewnić sobie większość we władzach PSL, włączył w skład NKW przybyłych do Stanów Zjednoczonych Stanisława Bańczyka, Stanisława Wójcika i Władysława Zarembę. Linia polityczna prezentowana przez Mikołajczyka cieszyła się wśród ludowców powszechnym poparciem. Członkowie PSL z Europy, a także Ameryki Północnej odrzucali postulaty Korbońskiego i Bagińskiego. Mikołajczyk, uzyskawszy przewagę w Prezydium NKW PSL, usztywnił swoje stanowisko. Efektem tego była wspominana już uchwała NKW PSL z 27 kwietnia 1949 r., odrzucająca możliwość porozumienia na podstawie konstytucji kwietniowej. Fakt ten podważył sens planowanego spotkania z Bieleckim i uniemożliwił zawarcie porozumienia z SN.

Uchwała NKW PSL postawiła w trudnej sytuacji PPS. Socjaliści ze względu na uchwały zjazdu w Pont-à-Lesse nie mogli zaakceptować koncepcji Mikołajczyka, natomiast nie zależało im na rozbiciu PSD, gdyż obawiali się bliższego związku z SN, jedynym możliwym partnerem. Socjaliści mieszkający w Stanach Zjednoczonych rozmawiali z Mikołajczykiem, jednak nie mieli złudzeń co do możliwości zmiany jego stanowiska. Stały kontakt utrzymywali również z Korbońskim i Bagińskim, którzy krytykowali kwietniową uchwałę NKW PSL. Korboński liczył, że w obliczu możliwego rozbicia PSD Mikołajczyk będzie musiał skorygować swoje stanowisko ${ }^{51}$.

Kwietniowa uchwała NKW PSL stanowiła punkt zwrotny w negocjacjach dotyczących utworzenia czwórporozumienia. Jedynym członkiem kierownictwa PPS wykluczającym sojusz z endekami pozostawał Ciołkosz. Podczas posiedzenia Sekretariatu PSD 15 lipca 1949 r. oświadczył, że PPS nie widzi możliwości koalicji ideowej z SN. Wyraził pogląd, iż należy utrzymać PSD, które winno stać się czynnikiem aktualnej inicjatywy politycznej i podstawą do tworzenia szerszej reprezentacji politycznej o charakterze parlamentarnym ${ }^{52}$.

Zgodnie z zapowiedziami ugrupowania PSD podjęły próbę utworzenia polskiej reprezentacji politycznej. Dodatkowym czynnikiem mobilizującym do działania było utworzenie 1 czerwca 1949 r. w Stanach Zjednoczonych Komitetu do spraw Wolnej Europy (KWE). Z założenia była to organizacja mająca wspierać przywódców politycznych i intelektualistów przebywających w USA, będących wychodźcami zza żelaznej kurtyny ${ }^{53}$. Twórcy KWE zakładali, że partnerami dla niego będą komitety narodowe, możliwie naj-

50 17 grudnia 1948 r. podczas posiedzenia Prezydium NKW PSL obradującego w trzyosobowym składzie (Mikołajczyk, Bagiński, Korboński) przegłosowano prezesa i doprowadzono do przyjęcia uchwały o wygaśnięciu mandatu prof. Kota jako delegata NKW PSL na Europę Zachodnią.

51 IPiMS, Kolekcja Tomasza Arciszewskiego, Kol. 97/9 B, List Władysława Zachariasiewicza do Tomasza Arciszewskiego, 31 V 1949 r., b.p.

52 APIN, Kolekcja Karola Popiela, Kol. 9/45, Protokół nr 14 posiedzenia Sekretariatu PSD z 15 VII 1949 r., b.p.

53 Szerzej na temat tej organizacji zob.: A.R. Johnson, Radio Wolna Europa i Radio Swoboda. Lata CIA i późniejsze, Wrocław 2014, s. 30-61; A. Mazurkiewicz, Uchodźcy polityczni z Europy ŚrodkowoWschodniej w amerykańskiej polityce zimnowojennej 1948-1954, Warszawa-Gdańsk 2016. 
bardziej reprezentatywne dla społeczności emigracyjnych. Partnera dla KWE nie mógł stanowić londyński ośrodek rządowy, ponieważ Stany Zjednoczone utrzymywały stosunki dyplomatyczne z rządem warszawskim.

Mikołajczyk dążył do sformowania komitetu narodowego, opartego na jak najszerszej bazie politycznej. Komitet będący reprezentacją polskiej emigracji politycznej stanowitby partnera dla rządu Stanów Zjednoczonych i pozostałych państw zachodnich. Lider ludowców liczył, że w osiągnięciu tego celu pomoże mu duża popularność, którą zdobył na Zachodzie, również dzięki działalności publicystycznej. Idei utworzenia komitetu narodowego nie popierali jednak potencjalni partnerzy: SN, PPS, NiD. Przeszkodą było tu przywiązanie członków tych ugrupowań do idei ciągłości Państwa Polskiego, symbolizowanej przez Rząd RP czy prezydenta, jak również obawa ich przywódców przed hegemonią Mikołajczyka.

W lipcu 1949 r. Ciołkosz przedstawił projekt powołania Polskiej Rady Jedności Narodowej. Radę o charakterze ciała parlamentarnego miały tworzyć PPS, PSL, SP i SN. Oprócz przedstawicieli stronnictw założycielskich w jej skład mieli wejść także przedstawiciele mniejszych ugrupowań. 19 lipca odbyła się konferencja PPS, PSL i SN, podczas której Bielecki przedstawił projekt deklaracji, zobowiązującej stronnictwa do uznania legalizmu, nienaruszalności granicy ryskiej i poparcia granicy zachodniej ${ }^{54}$. Mikołajczyk odrzucił projekt deklaracji, zakładającej wiązanie się formułą legalistyczną, natomiast wyraził gotowość wejścia PSL do RJN.

Projekt powołania RJN stał się przedmiotem kilkudniowych rozmów pomiędzy stronnictwami. PSL oraz SN zgłosiły do niego szereg przeciwstawnych uwag. Różnice, szczególnie w kwestii stosunku do konstytucji kwietniowej, okazały się zbyt duże. Rozmowy nie doprowadziły do porozumienia i postanowiono odłożyć je do połowy września.

Negocjacje lipcowe przyniosły natomiast zbliżenie stanowisk SN i PPS na płaszczyźnie stosunku do prezydenta Zaleskiego. Zakładano, że utworzona Rada będzie funkcjonować w ramach istniejącego porządku prawno-konstytucyjnego. Liczono przy tym, iż pod wpływem faktów dokonanych obóz prezydencki ustąpi miejsca koalicji trzech stronnictw ${ }^{55}$.

8 września rozpoczęła się kolejna runda rozmów pomiędzy stronnictwami PSD. Równolegle socjaliści negocjowali z endekami oraz PRW „NiD”, zakładając, że do wspólnego projektu przyłączy się również SP. Przedstawiciele PPS przekonywali SN do zgody na wejście PSL do RJN, przy zachowaniu odrębnego stanowiska w kwestii legalizmu. Ludowcy kwestionowali natomiast poszerzenie kręgu rozmówców o PRW „NiD”. Żądali także od SN deklaracji potwierdzającej zgodę na zachowanie przez poszczególnych partnerów swojego stanowiska wobec problemów konstytucji i legalizmu.

Kolejne posiedzenie przedstawicieli PPS, PSL i SN odbyło się 22 września. W jego trakcie Ciołkosz zaproponował partnerom przyjęcie następującego kompromisowego

\footnotetext{
A. Friszke, Adam Ciotkosz..., s. 475.

55 S. Kili a n, Myśl społeczno-polityczna Tadeusza Bieleckiego, Kraków 2000, s. 87.
} 
zapisu: „Stojąc na stanowisku nieprzerwanego istnienia Państwa Polskiego, RJN dążyć będzie do odbudowania władz Rzeczypospolitej w oparciu o stronnictwa polityczne i na zasadach rzetelnej demokracji. W dążeniu tym RJN nie uznaje następstw «sanacyjnych» zamachów stanu" ${ }^{56}$. SN nie zgodziło się na taki zapis, żądając wprowadzenia zwrotu o „ciągłości Państwa Polskiego”. Wówczas socjaliści przedłożyli kolejny projekt, uwzględniający zastrzeżenia SN: „RJN stoi na stanowisku ciągłości istnienia Państwa Polskiego oraz konieczności odbudowania tego porządku prawno-politycznego, który znalazł swój wyraz w tzw. porozumieniu paryskim z 1939 r., a który został głęboko naruszony w drodze «sanacyjnych» zamachów stanu" ${ }^{57}$. Takiej formuły nie zaakceptowali z kolei ludowcy. $\mathrm{Na}$ ich żądanie w dniu następnym odbyło się posiedzenie PSD, które jednak nie przełamało impasu politycznego.

\section{Rozpad Porozumienia}

Wobec braku kompromisu pomiędzy PSL a SN 26 września PPS wydała oświadczenie, iż nie widzi możliwości tworzenia RJN przez ugrupowania PSD. W tej sytuacji inicjatywę polityczną postanowili przejąć chadecy. 28 września Karol Popiel w imieniu PSL i SP złożył wniosek o powołanie Rady Politycznej Polskich Stronnictw Demokratycznych. Rada miała kierować się zasadami wyrażonymi w deklaracji z 15 listopada 1948 r. Proponowany zakres działania Rady był szeroki, obejmował między innymi reprezentowanie sprawy polskiej i interesów narodu polskiego wobec czynników zewnętrznych, informowanie społeczeństwa polskiego o dążeniach i osiągnięciach „narodów wolnego świata”, organizowanie pomocy dla kraju, opiekę nad emigracją polską ${ }^{58}$. Za wnioskiem opowiedziało się również SD, które w tym czasie weszło do PSD. Jednak najistotniejsze dla sukcesu tej inicjatywy było stanowisko socjalistów, którzy zastrzegli sobie miesiąc na podjęcie decyzji. PPS prowadziła równolegle rozmowy z $\mathrm{SN}$ w sprawie utworzenia wspólnej reprezentacji. Preludium do nich stanowiło wspomniane już porozumienie PPS, SN i PRW „NiD” z ppłk. Janem Kamieńskim. Członkowie kierownictwa PPS opowiadali się za porozumieniem z SN. Stanowisko takie podzielił w końcu także Ciołkosz, zniechęcony nieustępliwą postawą Mikołajczyka. Do odrzucenia wniosku o powołanie Rady Politycznej Polskich Stronnictw Demokratycznych wzywali również socjaliści mieszkający w Stanach Zjednoczonych. Otton Pehr twierdził, że w projektowanym ośrodku politycznym uczestniczyłoby jedynie PPS, część PSL (bez Korbońskiego i Bagińskiego) i część SP (Popiela). „Bardzo wątpię

56 IPiMS, Kolekcja Tomasza Arciszewskiego, Kol. 97/9 A, List Tomasza Arciszewskiego do nieznanego działacza PPS, 6 X 1949 r., b.p.

57 Ibidem.

58 AZHRL, PSL na U, sygn. 183, Wniosek Polskiego Stronnictwa Ludowego i Stronnictwa Pracy złożony na posiedzeniu PSD 28 IX 1949 r., b.p. 
- pisał do Arciszewskiego - czy taka Rada zdołałaby zyskać uznanie tak wśród Polaków, jak też wśród obcych. Tak jak stan dzisiejszy wzmacnia sanację i Zaleskiego, tak utworzenie tej Rady jeszcze bardziej wzmocniłoby pozycję sanacji" ${ }^{\text {"99 }}$. Jako przykład dobrej współpracy polskich stronnictw politycznych przedstawił sytuację w Stanach Zjednoczonych, gdzie PPS współdziała z SN, PRW „NiD” i PSL (Korboński i Bagiński).

Rozmowy pomiędzy PPS, SN, PRW „NiD” doprowadziły w październiku 1949 r. do uzgodnienia stanowiska politycznego. Socjaliści zgodzili się na rozpoczęcie procesu jednoczenia emigracji bez PSL, zastrzegając przy tym, że zamierzają doprowadzić do włączenia ludowców do nowej platformy politycznej ${ }^{60}$. Liczyli także na przyłączenie się SP i SD, co znacząco poszerzyłoby bazę ugrupowań powstającego ośrodka. Zdając sobie sprawę z faktu, że nie ma szans na przekonanie Mikołajczyka, usiłowali skłonić innych członków władz PSL do udziału w planowanej Radzie Politycznej. Socjaliści ze Stanów Zjednoczonych przekonywali Bagińskiego i Korbońskiego do wejścia do Rady. Namawiał ich do tego korespondencyjnie również Ciołkosz, proponując miejsca w jej władzach.

Pertraktacji pomiędzy PPS a SN nie udało się utrzymać w tajemnicy, jednak Mikołajczyk jeszcze w październiku nie wierzył w porozumienie socjalistów z endekami. Zakładał, że PPS nie zdecyduje się na zerwanie z PSL również ze względów finansowych. Przedstawiciel KWE De Witt C. Poole miał mu zadeklarować, że Komitet uzna jedynie reprezentację stronnictw z udziałem PSL.

Na posiedzeniu Centralnego Komitetu Zagranicznego PPS 22 października 1949 r. zadecydowano o odrzuceniu wniosku dotyczącego powołania Rady Politycznej Polskich Stronnictw Demokratycznych. 5 listopada CKZ PPS „z żalem” powiadomił o tym stronnictwa wchodzące w skład PSD ${ }^{61}$.

Kwestię udziału socjalistów w PSD usiłowało wyjaśnić jeszcze SP, którego prezydium 23 listopada wystąpiło z propozycją zwołania Komisji Porozumiewawczej PSD. W odpowiedzi CKZ PPS pismem z 1 grudnia poinformował, że socjaliści postanowili przystąpić do tworzącej się Rady Politycznej. Zaznaczono przy tym, że w niczym nie zmienia to dotychczasowego stosunku PPS do PSD, „którego członkiem pozostajemy w dalszym ciągu i którego Deklarację z 15 listopada 1948 r. uważamy w dalszym ciągu za wiążącą nas"62.

W październiku i listopadzie 1949 r. trwały rozmowy socjalistów (głównie Zaremby i Białasa) z przedstawicielami SP (Popiel, Sieniewicz, Biega), mające przeciągnąć chadeków na stronę tworzącej się Rady Politycznej. Kuszono ich między innymi możliwością

59 IPiMS, Kolekcja Tomasza Arciszewskiego, Kol. 97/9 C, List Ottona Pehra do Tomasza Arciszewskiego, 12 X 1949 r., b.p.

60 List Zygmunta Zaremby do Franciszka Białasa, 20 X 1949 r., [w:] Zygmunt Zaremba, Listy: 1946-1967, s. 289-291; IPiMS, Kolekcja Tomasza Arciszewskiego, Kol. 97/9 A, List Tomasza Arciszewskiego do działaczy PPS w Stanach Zjednoczonych, 21 X 1949 r., b.p.

${ }^{61}$ APIN, Kolekcja Karola Popiela, Kol. 9/45, Pismo CKZ PPS do Prezydium SP, 5 XI 1949 r., b.p.

62 Ibidem, Pismo CKZ PPS do Prezydium SP, 1 XII 1949 r., b.p. 
pozyskania przez Radę środków finansowych z KWE, w wysokości 15000 dolarów miesięcznie. Zaremba oświadczył rozmówcom, iż siła nowego ośrodka politycznego będzie tak duża, że doprowadzi zmiany na stanowisku prezydenta. Zdaniem Zaremby gen. Anders, prezes Głównej Komisji Skarbu Narodowego, po utworzeniu Rady miał wstrzymać wszelkie wypłaty na rzecz ośrodka prezydenckiego ${ }^{63}$. Jak wynika z zachowanych dokumentów, zabiegi socjalistów zachwiały solidarnością SP wobec PSL. Popiel w rozmowie z Białasem twierdzit, że chadecy nie chcą być identyfikowani z linią polityczną PSL, a szczególnie ze stanowiskiem Mikołajczyka. Wyraził zdziwienie z powodu upartego stanowiska PSL w sprawie legalizmu. Zdaniem Białasa, relacjonującego Arciszewskiemu rozmowę z prezesem SP, Popiel „osobiście uważa za celowe powołanie do życia porozumienia stronnictw, na razie bez PSL, gdyż nie można pozostawać biernym, zwłaszcza wobec aktywnego stanowiska sanacji”’64.

Podczas prowadzonych w listopadzie rozmów Zaremby z Sieniewiczem i Odorkiewiczem starano się wypracować zasady porozumienia, które byłyby możliwe do przyjęcia również przez ludowców. W końcu listopada chadecy przedstawili Zarembie propozycję sformułowań do platformy porozumienia i zasugerowali, aby do czasu wyczerpania możliwości kompromisu z ludowcami nie podejmować definitywnych posunięć politycznych ${ }^{65}$.

Ludowcy, zdając sobie sprawę z nacisku wywieranego na SP i SD, starali się zatrzymać te stronnictwa w PSD. W odpowiedzi na powstanie porozumienia PPS, SN i PRW „NiD” zamierzali sformować nowy ośrodek polityczny na bazie ugrupowań PSD. Usiłowali sprowadzić władze SP i SD do Stanów Zjednoczonych, aby całe kierownictwo nowego ośrodka przebywało w tym kraju. Dążyli do uniknięcia sytuacji utrudniającej funkcjonowanie PSD, gdy kierownictwo PSL przebywało w Stanach Zjednoczonych, kierownictwo SP w Paryżu, a kierownictwo PPS i SD w Londynie. Mikołajczyk interweniował w Departamencie Stanu w kwestii przyznania wiz dla Popiela, Sieniewicza i Olszewskiego. Zapewniano także partnerów, że bez PSL żadna reprezentacja polityczna nie zostanie uznana przez KWE ${ }^{66}$.

Powstanie Rady Politycznej utworzonej przez SN, PPS i PRW „NiD” ogłoszono 4 grudnia $1949 \mathrm{r}^{67}$ Chadecy ostatecznie 14 grudnia poinformowali socjalistów o swojej decyzji niewchodzenia do Rady Politycznej ${ }^{68}$. Była to dla PPS nieprzyjemna niespodzianka, gdyż

63 Ibidem, Pismo Prezydium SP do Prezydium PSL, 2 XI 1949 r., b.p.

${ }^{64}$ IPiMS, Kolekcja Tomasza Arciszewskiego, Kol.97/9 A, List Franciszka Białasa do Tomasza Arciszewskiego, 9 XI 1949 r., b.p.

65 List Zygmunta Zaremby do Franciszka Biatasa, 25 XI 1949 r., [w:] Zygmunt Zaremba, Listy: 1946-1967, s. 296-297.

66 APIN, Kolekcja Karola Popiela, Kol. 9/45, List Stanisława Wójcika do Konrada Sieniewicza, 26 XI 1949 r., b.p.

67 Układ o utworzeniu Rady Politycznej przywódcy PPS, SN i PRW „NiD” parafowali 11 listopada 1949 r.

${ }_{68} \mathrm{Na}$ decyzję SP Popiela miały zapewne wpływ także kwestie ambicjonalne. Popiel liczył, że pod jego przewodnictwem dojdzie do połączenia z grupą SP gen. Hallera. Drugi odłam SP nie chciał jednak uznać przywództwa Popiela, domagając się po ewentualnym połączeniu wyboru nowych władz. 
socjaliści byli przekonani o akcesie SP i SD do Rady. Przedstawiciele SP zapewnili natomiast o swoim pozytywnym stosunku do Rady i podjęciu wysiłków w celu doprowadzenia do porozumienia pomiędzy Radą a PSL. Przedstawiciele SD odpowiedzieli odmownie listem 28 grudnia, wyrażając nadzieję, że z czasem powstanie Rada obejmująca wszystkie stronnictwa polityczne ${ }^{69}$.

Ugrupowania tworzące PSD 15 grudnia uznały, że PPS, wchodząc do Rady Politycznej, złamała umowy zawarte 15 listopada $1948 \mathrm{r}$. i przestała być członkiem porozumienia. PSL, SP i SD postanowiły utrzymać tę platformę współpracy i działać zgodnie z zasadami deklaracji z 15 listopada ${ }^{70}$. Zadecydowano także o odbyciu następnego posiedzenia Komisji Porozumiewawczej PSD w Waszyngtonie.

22 marca 1950 r. do Stanów Zjednoczonych przybyli przedstawiciele SP: prezes Karol Popiel i sekretarz generalny Konrad Sieniewicz oraz prezes SD Stanisław Olszewski. Dwa dni później w Waszyngtonie odbyło się pierwsze w tym kraju posiedzenie Komisji PSD, podczas którego nakreślono plan dalszego działania Porozumienia ${ }^{71}$.

Kluczowe decyzje dotyczące przyszłości PSD zapadły w trakcie posiedzenia Komisji Porozumiewawczej 17 kwietnia 1950 r. Postanowiono zlikwidować uznane za niewydolne dotychczasowe organy Porozumienia: Komisję Porozumiewawczą i Sekretariat, a w ich miejsce powołać inne, z kompetencjami dostosowanymi do aktualnej sytuacji. W kwietniu zadecydowano także o utworzeniu nowego ośrodka politycznego dla realizacji celów deklaracji PSD. 2 maja 1950 r. stronnictwa tworzące PSD ogłosiły powołanie Polskiego Narodowego Komitetu Demokratycznego.

\section{Zakończenie}

Utworzenie Rady Politycznej położyło kres koncepcji Mikołajczyka dążącego do utworzenia komitetu narodowego skupiającego główne stronnictwa demokratyczne. Było też bezpośrednią przyczyną pierwszego poważnego rozłamu w emigracyjnym PSL. W skład władz Rady weszli (jako osoby prywatne) Kazimierz Bagiński i Stefan Korboński. Bagiński został jej wiceprzewodniczącym, natomiast Korboński wiceprzewodniczącym Wydziału Wykonawczego Rady. Konsekwencją było usunięcie ich z PSL w styczniu 1950 r.

PSD okazało się tworem słabym, niezdolnym do prowadzenia aktywnej działalności wśród emigracji. Pomiędzy dwoma głównymi ugrupowaniami występowały zasadnicze różnice w kwestii uznania legalizmu władz państwowych. Podziały miały miejsce także

${ }_{69}$ IPiMS, Kolekcja Tomasza Arciszewskiego, Kol. 97/19, List Tomasza Arciszewskiego do Stefana Korbońskiego, 29 XII 1949 r., b.p.

70 Uchwata Komisji PSD, „Jutro Polski” 1949, nr 22 (169), s. 1.

71 PSD na nowej drodze, ,Jutro Polski” 1950, nr 7 (176), s. 1. 
wśród kierownictw tych ugrupowań. Powodowało to często dezorientację partnerów z porozumienia, utrudniało, a często wręcz uniemożliwiało zgodną współpracę. Przykładem mogą być choćby kwestie związane z powołaniem Rady Polskiej Unii Europejskiej czy Podkomisji PSD dla spraw Emigracyjnych.

Oprócz rozbieżności w sprawach legalizmu czy konstytucji kwietniowej znaczenie miały także ambicje osobiste, wzajemna nieufność oraz animozje pomiędzy liderem PSL a przywódcami PPS (Arciszewski, Kwapiński).

Porozumienie miało być wstępem do odbudowy czwórporozumienia z czasu okupacji. Jednak endecy nie przystąpili do Porozumienia. SN stojące twardo na stanowisku legalistycznym nie było zainteresowane wejściem do PSD. Dążyło do jego rozbicia i sformowania nowej platformy politycznej, już bez PSL (a przynajmniej bez Mikołajczyka i Kota). Cel ten udało się osiągnąć poprzez utworzenie Rady Politycznej.

Usunięcie PPS z grona Porozumienia Stronnictw Demokratycznych, a równocześnie dywersja socjalistów wobec PSL polegająca na zachęceniu Korbońskiego i Bagińskiego do wejścia do Rady Politycznej doprowadzity do wytworzenia wzajemnej niechęci i nieufności pomiędzy tymi ugrupowaniami. Wykluczyło to możliwość jakiegokolwiek porozumienia na długi okres. Do kolejnego zbliżenia PSL i PPS doszło dopiero po prawie dwóch dekadach, już po śmierci Mikołajczyka.

\section{BIBLIOGRAFIA}

\section{Źródła archiwalne:}

Archiwum Polskiego Instytutu Naukowego w Ameryce (The Polish Institute of Arts and Sciences of America) Kolekcja Karola Popiela, Kol. 9/45.

Archiwum Zakładu Historii Ruchu Ludowego w Warszawie

Polskie Stronnictwo Ludowe na Uchodźstwie, 183.

Biblioteka Uniwersytecka Katolickiego Uniwersytetu Lubelskiego Jana Pawła II

Rkps 2007.

Rkps 2009.

Instytut Polski i Muzeum im. gen. Sikorskiego w Londynie

Kolekcja Stanisława Olszewskiego, Kol. 660/21.

Kolekcja Tomasza Arciszewskiego, Kol. 9719, 97/26, 97/9A, 97/9B, 97/9C

Studium Polski Podziemnej w Londynie

Kolekcja Adama Ciołkosza, Kol. 133/406.

Archiwum Instytutu Hoovera

Dokumenty Stanisława Mikołajczyka, sygn. 800/22/0/-/85, 800/22/0/-/111.

\section{Źródła drukowane:}

Deklaracja Porozumienia Stronnictw Demokratycznych, „Jutro Polski” 1948, nr 21 (145), s. 1-2.

Deklaracja Porozumienia Stronnictw Demokratycznych, Londyn 1948. 
Komunikat PSD, „Jutro Polski” 1949, nr 14 (161), s. 1.

Komunikat Sekretariatu PSD, „Jutro Polski” 1949, nr 10 (157), s. 1.

Uchwata Komisji PSD, „Jutro Polski” 1949, nr 22 (169), s. 1.

Uchwata Związów Ziem Wschodnich RP, „Lwów i Wilno” 1948, nr 96, s. 1.

List Zygmunta Zaremby do CKZ PPS w Londynie, 15 III 1949 r., [w:] Zygmunt Zaremba, Listy: 1946-1967, oprac. O. Blaton, A. Friszke, Warszawa 2000, s. 276-278.

List Zygmunta Zaremby do Franciszka Biatasa, 20 X 1949 r., [w:] Zygmunt Zaremba, Listy: 19461967, oprac. O. Blaton, A. Friszke, Warszawa 2000, s. 289-291.

List Zygmunta Zaremby do Franciszka Biatasa, 25 XI 1949 r., [w:] Zygmunt Zaremba, Listy: 19461967, oprac. O. Blaton, A. Friszke, Warszawa 2000, s. 296-297.

List Zygmunta Zaremby do Stefana Korbońskiego, 4 V 1949 r., [w:] Zygmunt Zaremba, Listy: 19461967, oprac. O. Blaton, A. Friszke, Warszawa 2000, s. 279-281.

\section{Opracowania:}

Buczek R., Stanistaw Mikotajczyk, t. 2, Toronto 1996.

Friszke A., Życie polityczne emigracji, Warszawa 1999.

Friszke A., Adam Ciotkosz. Portret polskiego socjalisty, Warszawa 2011.

Górecki D., Polskie naczelne wtadze państwowe na uchodźstwie w latach 1939-1990, Warszawa 2002.

Johnson A.R., Radio Wolna Europa i Radio Swoboda. Lata CIA i późniejsze, Wrocław 2014.

Kilian S., Myśl spoteczno-polityczna Tadeusza Bieleckiego, Kraków 2000.

Kornat M., Konstytucja za wszelka cenę. Prezydent RP na uchodźstwie August Zaleski (1947-1972), [w:] Prezydenci i Rzady RP na uchodźstwie 1939-1990. Wybrane problemy z historii polskiej emigracji, red. H. Taborska, M. Fleming, A. Rzegocki, Londyn-Kraków 2013.

Eukasiewicz S., Partia w warunkach emigracji. Dylematy Polskiego Ruchu Wolnościowego „Niepodlegtość i Demokracja” 1945-1994, Lublin-Warszawa 2014.

Mazurkiewicz A., Uchodźcy polityczni z Europy Środkowo-Wschodniej w amerykańskiejpolityce zimnowojennej 1948-1954, Warszawa-Gdańsk 2016.

Mikotajczyk z Kongresem Polonii, „Dziennik Związkowy (Zgoda)” 1947, nr 296, s. 1.

PSD na nowej drodze, „Jutro Polski” 1950, nr 7 (176), s. 1.

Siwik A., Polska Partia Socjalistyczna na emigracji w latach 1945-1956, Kraków 1998.

Stanek P., Stefan Korboński (1901-1989). Dziatalnośćpolityczna i spoteczna, Warszawa 2014.

Wolsza T., Rząd RP na obczyźnie wobec wydarzeń w kraju 1945-1950, Warszawa 1998. 